\title{
The elephant in the (class)room: The debate over Americanization of Canadian universities and the question of national identity
}

\author{
Brooke Anderson \\ This study was conducted under the supervision of Professor Matthew Hayday, \\ Department of History, College of Arts \\ University of Guelph
}

\begin{abstract}
Focusing primarily on the period from 1968 to 1970, this essay analyses how a campaign led by two Carleton University professors, Robin Mathews and James Steele, to defeat "Americanization" in Canadian universities, morphed into a crucial nationwide debate. Ultimately, it will find that regardless of academic or social rank or citizenship, all participants in the debate relied on one common idea to support their arguments and criticize their opponents: that of the 'colonial mentality', or the notion that Canadians unquestionably accepted their country as subservient to the United States. Ultimately, this paradoxical usage of postcolonial themes represented an underlying ambivalence in regards to what was being debated in the first place. Thus this essay strives to address how a specific dispute within academia could, in Mathews and Steele's words, evolve into a "struggle for the very existence of Canada as a self-respecting and independent community" [1a]. Moreover, it contributes to a deeper understanding of Canadian-American relations and the recent debate on Canadian universities' hiring practices, which continues to be an issue nearly forty years later. In doing so it presents a fascinating case study of national identity within postcolonial frameworks.
\end{abstract}

Tn a CBC news commentary on January 2, 1969, Carleton University history professor H. Blair Neatby summed up the 1960s in Canada as a "decade of obsession with the American menace" [2]. Taken alone, the statement might seem slightly exaggerated (and perhaps it was), but it was really part of a counter-reaction to the "latest" concern that Americans were taking over Canada's English-speaking universities. Blair's colleagues, English professors Robin Mathews and James Steele, had just recently launched a campaign calling for stricter policies and regulations to prevent further "Americanization" from taking place, and to instead promote a visible Canadian majority. As historian Patricia Jasen has noted, hiring non-Canadians could seem backward at a time when many Canadians were becoming increasingly conscious of their national identity [3a]. Emerging from this latter group of nationalists, intellectual Hugh MacLennan delivered hyperbole to rival Neatby's when he called Americanization of universities "a programme of national suicide" [4a]. Jeffrey Cormier has written that the pressure to "Canadianize" was heavily concentrated within the university system [5a], but he fails to explain why this was exactly. The question is significant because it addresses how a specific dispute within academia could, in Mathews and Steele's words, evolve into a "struggle for the very existence of Canada as a selfrespecting and independent community" [1b]. Moreover, it contributes to a deeper understanding of the recent debate on Canadian universities' hiring practices, which continues to be a "stubborn" issue nearly forty years later $[6,7,8]$. In doing so it presents a fascinating case study of that most elusive and controversial theme in Canadian history: the question of national identity.

Focusing primarily on the period from 1968 to 1970 , this essay will examine the range of factors that transformed the Carleton episode into a nationwide debate, from expansion efforts and a nationalist climate, to the student movement and the university's perceived role(s) in society. Ultimately, it will find that whether they were scholars, students, or administrators, and regardless of their own opinions, everyone in the debate utilized a common idea to bolster their arguments and criticize their opponents: that of the 'colonial mentality', or the notion that Canadians unquestionably accepted their country as subservient to the United States. The participants in the debate grappled with defining and determining the relationships between nationality and citizenship, pro-Canadianism and antiAmericanism, academic freedom and limitation, university and state, and so forth, sometimes building or deconstructing binary oppositions. More often than not, however, these concepts actually meant one in the same thing. Ryan Edwardson's passing mention of postcolonial theorist Partha Chatterjee's argument, that non-European nationalism has almost always been an issue of colonialism, thus deserves another look [9]. Perhaps the paradoxical usages of colonial mentality, from all sides, were simply an extension of this underlying ambiguity in regards to what was being debated 
in the first place. On the one hand, nationalist scholars could point to their adversaries as proof that Americanization was a looming threat, since even intellectuals were willing to passively accept and defend it rather than support their own country. Yet on the other hand, the latter could just as easily accuse the nationalists of being afflicted with a 'collective inferiority complex', since their rationale for a quota system implied that Canadian scholarship was second-rate. No matter how it was framed, the ever-present colonial mentality complicated, intensified, and prolonged the debate, and constantly served to remind that the university, as an institution, was crucial to the broader question of Canadian sovereignty.

At the outset of the sixties, the sheer volume of young people from the baby boom, combined with a newfound appreciation for a post-secondary degree, forced major expansion of universities across the country. Existing universities were enlarged and a host of brand new ones created as the higher education system struggled to accommodate an exponentially growing student populace. In order to cope with enrolment numbers, Canadian universities looked to the example of the American 'multiversity' and implemented ad hoc policies. Unfortunately, many of these structural changes achieved quantity at the expense of quality. Having set off for university expecting to join an enriching 'community of scholars', students of the sixties quickly realized that the dream had crumbled along with the ivory tower, and grew to resent the depersonalized 'service station' that the university had become [3b].

A major area of discontent was the curriculum, particularly in the arts and social sciences. Students complained about irrelevant course material, the preoccupation with empiricism, the distortions of Canadian history (if it was taught at all), and the complete lack of Canadian literature. They increasingly blamed the influx of American scholars who had arrived during the period of hasty expansion in the early sixties, when Canadian universities had not only imitated the American model, but had recruited Americans to fill their thousands of vacancies $[10,3 \mathrm{c}]$. Ryan Edwardson demonstrates that in the year 1960-61 there were 7,760 full-time faculty positions in Canada and that ten years later the number had inflated to 24,612, but that throughout the entire decade Canadian universities had only produced about 5,600 $\mathrm{PhDs}$ available to work in academia. Although there were Canadians who had completed their graduate work in the United States, the total number could still not come close to satisfying the huge demand. Universities thus had little choice but to look beyond their own borders. In the short-term, this strategy worked remarkably well, but already by the mid sixties the cracks were beginning to show. Ernest Sirluck, Dean of University of Toronto Graduate Studies delivered an ominous warning in 1966: "we will not escape the vulnerability of our academic colonialism until we cease to bum a free ride" [11]. Student activist Bob Rae would later ask, along the same lines: "What is enlightening about importing U.S. course materials, professors? Canada's status as intellectual branch plant colony is complete unless we can nourish our own resources" [12].

These objections augmented concerns for Canadian identity that had been gathering force in social, economic, and cultural spheres throughout the mid to late sixties. Polemic treatises such as George Grant's Lament for a Nation (1965) feared that Canadian sovereignty, swallowed up by the American empire, would soon cease to exist. Nationalist dialogue urged Canadians to reclaim it, protect it, celebrate it. Conditions were clearly ripe for a manifesto on the Americanization of universities when Robin Mathews and James Steele burst onto the scene. As Edwardson points out, they were certainly not the first to broach the subject [11]. They were, however, the most prominent and successful spokesmen for the issue. By treating it as a case of colonial mentality, they were able to tap into trends in opinion, deepen the sense of grievance, and relate to the larger social and ideological currents [5b].

Mathews and Steele's basic argument was that the sharp increase in American scholars was detrimental to Canadian universities, and by extension, Canada as a whole. They believed that if Americanization continued unchecked, the university would dissolve into nothing but a satellite campus, and would take Canada down with it. Distressed by such bleak prospects, Mathews and Steele requested an emergency meeting of the Carleton University Academic Staff Association (CUASA) on November 25, 1968 to examine the situation more closely [13]. They distributed a memorandum that put forth five motions as "minimal first steps" to "be taken immediately to counter the trend". The first two were that Canadians should comprise a clear twothirds majority of full-time faculty, and that if ever a department failed to meet this standard, it would have to prove that it had done everything in its power to actively seek Canadian applicants by advertising for at least one month in a minimum of three Canadian publications, in addition to University Affairs and the Canadian Association of University Teachers Bulletin. The last three recommendations were that all new appointments to administrative positions after September 1, 1969 must be Canadian citizens, that the CUASA be granted a record of the citizenship of Carleton faculty, and that they obtain information about the citizenship of all Canadian faculties from the Canadian Association of University Teachers for the purpose of formulating a national policy [14a].

In response to Mathews and Steele's request, the CUASA voted to hold a general meeting on January 16, 1969. Unimpressed, Mathews and Steele issued a second memorandum stating that time was of the essence, as recruiting of new faculty was to begin in a few weeks time [15]. Four days later, the CUASA announced that it would grant Mathews and Steele a special meeting scheduled for December 11, 1968 [16]. While this bickering had been going on, however, two professors from the Department of Sociology, Bruce McFarlane and Denis Forcese, had 
circulated their own petition against Mathews and Steele, supporting "the principle of an academic community of excellence, dependent upon criteria of professional and academic performance, and not criteria of race, gender, nationality, or any like basis" [17]. Mathews and Steele contested the term "academic community", agreeing that every scholar should always be judged in the way that McFarlane and Denis described, but that as part of a collective group, the individual should naturally have a vested interested in the greater culture and community to which that group belongs [18].

As the confrontations escalated, Carleton faculty became bitterly divided. Consequently, the meeting set for December 11 was virtually over before it even had a chance to begin. Forcese's scathing remark to Time magazine, "I hope we can club these people to death when it comes up at the meeting", certainly gave little reason to be optimistic. He, McFarlane, and others distributed Human Rights pamphlets on ethical employment practices ten minutes before the meeting, claiming that Mathews and Steele's propositions violated the Ontario Human Rights Code. The tactic may have been misinformed "emotional blackmail", as Mathews later called it [19], but it worked nonetheless. The amount of hostility directed at Mathews and Steele was greater than they had anticipated. Motions two through five were crushed by a vote of 135 to five, and worse, the first motion was amended to read that all faculty members shall be employed "on the basis of academic competence regardless of citizenship" [20]. For Mathews and Steele, the meeting was an utter disaster, but it did not end there. In fact, it was only the beginning of a much larger and much fiercer debate.

The peculiar set of circumstances that contributed to Mathews and Steele's initial call for concern have been alluded to, but the questions remain: Why the university of all places? How did it come to be such an explosive site of protest? Major factors distinguished it from other features of Canadian life, such as television or print media, which had also undergone intense Americanization over the years. First and foremost was the involvement of the students. Mathews and Steele have recently criticized Cormier for overlooking students' contributions in his account of the debate. They stress that students were essential to the movement as they were among the first to challenge the absence of Canadian materials in the curriculum, and consistently supported their professors' suggestions for improvement [21a]. Some students, such as James Laxer, criticized their fellow New Left leaders for blindly imitating and idolizing American activists, instead of focussing on issues and developing strategies pertinent to their colonial context. Laxer attributed this ignorance to a "sense of impotence common to colonized people" [22]. With the help of Laxer and others, however, the New Left matured and became instrumental in cultivating the nationalist debate, as young activists increasingly sought definitions of what it meant to be Canadian and questioned their country's role as an exploiter or an exploited [23a, 24a]. A small number of radicals rejected Mathews and Steele's "sentimental nationalism" altogether on the basis that an international revolution against capitalism and imperialism was the real priority $[11,24 \mathrm{~b}]$. In any case, Americanization was a hot topic for students, and it coincided remarkably well with their efforts to rectify the "master-slave" dynamic of the multiversity classroom [25].

In 1967, Michael Walzer praised this latter response as "one of the most impressive instances of the New Left defence of local autonomy and small-group activism" [26], but the New Left appeared to be increasingly anxious about national autonomy as well. There was an intimate parallel, within the university setting and beyond, between students' aspirations to power and the nationalists' objectives. Both wanted to be treated as adults and equals, free to make the important decisions affecting their lives without the interference of some distant, oppressive authority. In short, they expected fair representation — anything less was tantamount to colonial subjugation. Student activists frequently used colonial rhetoric to enhance their arguments for parity and greater self-government. For instance, Commission on University Government co-chairman, Gary Webster, declared that the university's hierarchical structure relegated students to a role of "psychological dependency" [27a]. Yet student leaders also appreciated that their "struggle for academocracy" was merely one aspect of the national problem [27b]. As Pete Warrian, president of the Canadian Union of Students phrased it, the push for "personal liberation within education" had to be linked to the push for national liberation. Canada's only hope avoiding a colonial fate rested on a "fundamental redirection" from within the universities, for the processes could not be separated [25]. University of Toronto President, Claude Bissell, hinted at this in 1968 when he analogized effective student government to running a democratic country. Both, he wrote, depended on "a sense of loyalty" [28a]. The context and timing of student action for university reform were thus significant factors in shaping Mathews and Steele's debate into something worthy of national attention. Student demands justified and energized the nationalist cause, while conversely, nationalist fears of Americanization imparted student demands with a sense of integrity and necessity. What bound the two sides together in such a mutually beneficial relationship was their shared notion of the colonial mentality.

Mathews and Steele's debate also owed its longevity to the popular perception of the university. Just as students viewed the university as a "mini-state" or "mini-world" [23b], social and intellectual elites and informed citizens recognized it as one of modern society's most sacred hubs. As a result, anything that affected or occurred within the university was thought to have some bearing on society at large. Universities, like today, were sites of social construction, knowledge production, and dissemination. Julyan Reid, co-editor of the 1969 publication, Student Power and the Canadian Campus, called them "the most sensitive institutions in our whole culture...they create the 
next generation, the next world" [29]. Because it was a key centre of national definition, the university was considered by many to be the ultimate battleground for combating Americanization. As a "socializing agent" it offered massive potential for nurturing the identity of young people, while academics' intellectual capital made them capable of greatly contributing to "the task of nationhood" [11].

To a great extent, the fact that Mathews and Steele's base was the university, in argument and reality, made their message seem credible and imperative. Michael Butler and David Shugarman, who published an article in the Journal of Canadian Studies supporting Mathews and Steele, expressed that the outcome of the university's fight against Americanization would more or less determine Canadian consciousness [30a]. Likewise, economist Melville Watkins avowed that the university was "the last bastion from which to insist that Canada regain her independence" [31]. Such sentiments evoked the idea that control of language, discourse, and education was the most effective strategy of colonial conquest. The loss of Canada's best and brightest institutions to Americanization would inevitably cripple the nation and confirm its colonial status. Hugh MacLennan reiterated this at the Montreal Symposium on DeCanadianization in 1969. In keeping with "at least a century and a half" of discussion on the topic, he concluded that a Canada without command of its own universities would be "nothing but a geographical expression" [4b]. The view that aligned higher education with national identity clearly informed Mathews and Steele's argument, and it appealed to a broad audience. Yet it was also the point that critics most frequently attacked, twisting the same colonial mentality to suit their own opinions.

The controversy played out in academic circles, public talks, television appearances and debates, and quarrelling letters and articles in major newspapers such as The Globe and Mail and The Toronto Star. For all the support Mathews and Steele enjoyed [11], they faced just as much animosity. They recounted a long list of terms that had been used to describe their propositions: "immoral, illiberal, racist, neoNazi, proto-fascist, chauvinistic, anti-American, protectionist, restrictionist, and intellectually obscene" [1c]. In their review of Cormier's book, they criticized his neglect of "the malignant quality, and even the viciousness, that sometimes marked discussions of the issue", which were not only important context for the language and strategies used, but vital indicators of how heated the debate could get [21b].

The main tension was between the traditional liberal ideology that knowledge knew no borders, which technically meant that teachers' nationalities should be irrelevant, and the belief that one of the university's most critical functions was to generate and perpetuate the cultural identity of its respective society [32]. Mathews and Steele stressed that teaching and research were not "conducted by disembodied minds in a metaphysical world of learning", but were carried out "by particular men, in particular places, at particular times, about particular problems and in the context of particular communities" [14b]. In reply, their critics argued that Canadians should be thankful and proud that so many Americans had agreed to work in Canadian universities. They had raised standards and salaries and made expansion possible, putting Canada in the enviable position of a reverse brain drain [33a]. Biologist R.J. Doyle went so far as to say that the American presence had a "civilizing and stimulating influence" and an "important biological benefit" for Canadians, since it would improve the genetic pool. "We need all we can get", he said, in a June 1969 issue of The Globe and Mail [34]. It was an extreme observation, but it encapsulated the frustration at what Mathews and Steele were trying to do. Social work professor James Gripton worried that the negative ramifications, namely a jeopardized academic reputation and limiting of intellectual freedom, would outweigh anything positive that could come of socalled Canadianization [35]. Sociologist Bernard Gustin believed that if universities closed their doors to the international community, they would doom themselves, and all of Canada, "to the stagnation of a provincial backwater" [36].

Nationalists, of course, interpreted such attitudes as embodying the colonial mentality which had allowed Americanization to happen in the first place. To them, those comments revealed how rampant the colonial mentality really was. In response to Forcese's argument that the quota system would reduce the quality of instructors, Mathews scorned sarcastically: "I fear he has a colonial mind...Poor, inferior Canadians" [37]. Butler and Shugarman also reckoned that critics" equating of scholastic "excellence" with American standards verified their absolute lack of confidence in Canadians. They too concurred that the concept of colonial mentality was "an essential explanatory tool for understanding the process by which Americanization occurred" [30b]. They believed that the Canadian psyche had to be seriously reoriented if universities were to "throw off the shackles of colonial mentality" [30c]. Critics shot back that the need to privilege nationality in hiring practices betrayed the basic tenets of liberal education, and undermined the nationalists' whole argument in its presumption that Canadians required regulation to make it in academia. To do so, historian Ramsay Cook claimed, would be akin to admitting that Canadians were less capable than their foreign counterparts. He firmly believed that competence should be the "sole standard" in determining allocation of jobs and promotions [33b].

Consequently, it could be challenging to distinguish who was on what side of the debate without a closer analysis of their arguments. For instance, humanities professor John Conway quoted Gwen Matheson in a letter published in The Globe and Mail: "A spectre is haunting Canada. It is the ghost of creeping colonialism. We have ourselves to blame. Canadians consider themselves second-rate" [38a]. It is interesting to compare it to music composer Barbara Pentland's assertion that "the whole aspect of our colonial attitudes has been a continually self-defeating defect" [39a]. 
From these excerpts alone, it would be difficult to ascertain whether Matheson, Conway, or Pentland actually backed Mathews and Steele's proposed schemes or not, because they all engaged with the colonial mentality in such similar ways. As it turned out, Conway followed the quote by saying that only people "profoundly unsure of themselves would interpret a great compliment as a threat" [38b]. In other words, Canadians should get over their insecurities and realize how fortunate they were to have so many Americans in their universities, and should utilize the opportunity to their advantage. In contrast, the quote from Pentland appeared in a letter she sent to Mathews offering her "wholehearted support" [39b]. Undoubtedly, a great deal of the friction and complexity of the debate stemmed from this paradoxical nature of the colonial mentality.

Cormier verges on stating the obvious when he points out that views of the United States have always formed an integral part of Canadian nationalism, and that efforts at Canadianization have most often been in reaction to some perceived American threat [5c], but Mathews and Steele's critics routinely saw anti-Americanism as a symptom of the colonial mentality itself. A socialist journal published by Vanguard, entitled Canada-U.S. Relations, found a letter by Mathews problematic because he treated Americans as "one solid lump of reaction". The author(s) of the piece deemed this the crudest sort of anti-Americanism there was - a poorly disguised perspective of "utter pessimism and defeat" [40]. Terence Crowley condemned Butler and Shugarman's defense of Mathews and Steele as "sloppy and indiscriminate" propaganda. Like Vanguard, he questioned assumptions which relied on parochial stereotypes of American academia, especially those that summarized its values as nothing more than quantification, mechanization, and standardization. He rejected the generalization that quantity trumped quality for all American scholars, and that such 'corrupt' values were exclusive to them alone [41a]. For Crowley, that kind of thinking was far too vague and simplistic. Rather than advancing the nationalist cause, the assault on supposed American "agents of assimilation" diverted attention from the real source of the problem: the multiversity. Crowley concluded that the nationalist viewpoint perpetuated the "collective inferiority complex which has always manifested itself in a naïve and illinformed anti-Americanism" in Canada. From his stance, Mathews and Steele's mission boiled down to prejudice, not scholarship [41b]. Alternatively, it is important to note that Mathews and Steele considered themselves "pro-Canadian" rather than anti-American [42]. As with their other rebuttals, they argued that those who interpreted their actions as antiAmerican did so because they lacked faith in their own abilities as Canadians. Once again, all the arguments revolved around the concept of colonial mentality, which kept the debate going at a quick and aggressive pace, but stalled the amount of progress that could be accomplished.

This lack of consensus was extremely troubling to the nationalists given their conviction that time was running out.
To them, complete Americanization of the universities, and then of Canadian society, was imminent unless drastic action was taken right away. By May of 1969, Mathews was clearly exasperated: "I will not sit back and hear what I consider nonsense spoken about the present problem. We don't have time. We don't have time" [original emphasis] [5d]. Political scientist Gad Horowitz put it plainly: "Let us not mince words; survival is the issue...the prospect of total economic and cultural integration into American society is real and immediate...moderation will be the death of us" [43]. Apparently, some people in the United States also felt that it was only a matter of time before Canada caved. Claude Bissell, who spent a sabbatical at Harvard in 1968, noted that a good number of students instantly walked out of his social science class when they heard it was about Canada [28b]. Bissell admitted that students' interest "tended to confine itself to doubts as to whether Canada could survive as nation, or, indeed, should really attempt to survive". It was somewhat ironic, then, that his other teaching duty was "Victorianism in the British Commonwealth" [44]. Both classes were basically themed around the colonial mentality. Agitation over the "extinction" of Canada, therefore, was not unfounded, but by the early seventies the number of groups that were taking up Mathews and Steele's cause seemed to indicate that Canada would endure after all.

In 1969, Mount Allison University introduced the country's first comprehensive undergraduate program in Canadian Studies, and the Ontario Institute for Studies in Education held a three day conference on the same topic. These initiatives helped bring about the non-profit Canadian Studies Foundation and coincided with the founding of the Committee for an Independent Canada in 1970 [11]. The year 1972 saw the release of budding literary icon Margaret Atwood's book, Survival: A Thematic Guide to Canadian Literature. Attuned to the nationalist discourse of the period, she described the book as charting the "experience of being a victim in a colonial culture" [11]. Meanwhile, the Canadian Sociology and Anthropology Association formed subcommittees to investigate the degree of Americanization in hiring, content, funding, admissions, and more. It reported in December of that year that Canadian interests were disadvantaged and recommended that department-head positions be exclusively set aside for Canadian citizens, that existing department heads and deans confer priority to Canadian candidates, and that seventy-five percent of graduate students be Canadians. There was still plenty of resistance to nationalist reforms - some members of the CSAA linked the recommendations to "fascism, racism, and encouragement of mediocrity" [11] — but the fact that various other commissions like the Association of Universities and Colleges of Canada Commission on Canadian Studies (1972) and the Canadian Political Science Association Committee on Canadian Content (1973) drew similar conclusions as the CSAA suggested that support for Canadianization had grown significantly since Mathews and Steele's first debate at Carleton. 
The momentum continued into the mid-seventies as federal expansion of Canadian Studies programs and funding for cultural organizations further legitimized their claims [11]. In a 1977 article titled "Notes on the Canadian Professoriate", Janet Scarfe and Edward Sheffield wrote that the "fracas" sparked off by Mathews and Steele "has continued, almost unabated" [45]. It seems that the amount of media attention and controversy was enough to influence the Trudeau government, however reluctant, to makes changes to immigration regulations in regard to faculty hiring. The CSAA, for instance, enjoyed particular success in lobbying both the provincial and federal governments and creating a meaningful conversation on the issue [46]. By the eighties, then, Canadianization had become well institutionalized. Mathews and Steele's proposed quota system was never adopted, but overall Americanization of Canadian universities was no longer viewed as a major threat since most faculties were eventually able to strike a balance mindful of both academic excellence and cultural prerogatives. Champion of Canadian Studies and founding president of Trent University, T.H.B. Symons, best summarized the need for such compromise in a 1979 speech at Mount Allison University: "In promoting Canadian studies we should not confuse nationalism and education. In pointing to the need for such studies, I think we must take care to make sure that they are not turned into an exercise in flagwaving" [5e, 11].

It is thus important to remember that Mathews and Steele's zealous nationalism was not necessarily representative of what went on behind the scenes. Hundreds, if not thousands of dedicated academics worked steadily to bring Canadian materials into their classrooms, while students formed a broad base of support. Far from being a simple dichotomy, the debate belonged to a much more dynamic and multifaceted movement [21c]. Throughout the period from 1968 to 1970, expansion efforts, a nationalist climate, student reform, and the university's perceived role(s) in society were among the leading factors that accelerated Mathews and Steele's grievances at Carleton to a critical Canada-wide debate. The concept of the colonial mentality was so ubiquitous in each of these areas that it became the vital point which anyone could use, at any time. Regardless of whether they supported or opposed Mathews and Steele's mantra, or whether they were on the offensive or defensive end of the debate, all participants resorted to using the colonial mentality in paradoxical ways. It is somewhat ironic, then, that over thirty five years after the fact, Mathews and Steele harshly criticized Cormier's book, which attempted to analyse their contributions to the Canadianization movement, for applying American theories which had "little or no relevance" to understanding the problem in a Canadian context. They called it, appropriately: "neo-colonialist" [21d].

\section{REFERENCES}

1. "The Problem: A Statement by the Editors," in The Struggle for Canadian Universities, a.11; b.11; c.7.

2. "C.B.C. broadcast by Professor Neatby, January 2, 1969," in The Struggle for Canadian Universities, eds. Robin Mathews and James Steele (Toronto: New Press, 1969), 42-43.

3. Patricia Jasen, "In Pursuit of Human Values (Or Laugh When You Say That)," in Youth, University, and Canadian Society, eds. Paul Axelrod and John G. Reid (Kingston and Montreal: McGillQueen's UP, 1989), a.258; b.247-248; c.256-258.

4. "Address by Hugh MacLennan to the Montreal Symposium on deCanadianization," in The Struggle for Canadian Universities, a.148; b.144.

5. Jeffrey J. Cormier, The Canadianization Movement: Emergence, Survival, and Success (Toronto: UTP, 2004), a.9; b.47, 29; c.45; d.27; e. 193

6. Jeffrey J. Cormier, "Nationalism, Activism, and the Canadian Sociology and Anthropology Community, 1967-1985," The American Sociologist 33, no. 1 (2002): 12-13.

7. Christine Overall, "Faculty Hiring," University Affairs, 6 October 2008, http://www.universityaffairs.ca/faculty-hiring.aspx.

8. Wayne Fenske and Louis Groarke, "PhD: to what end?" University Affairs, 9 November 2009, http://www.universityaffairs.ca/phd-towhat-end.aspx

9. Ryan Edwardson, “"Kicking Uncle Sam Out of the Peaceable Kingdom': English-Canadian 'New Nationalism' and Americanization," Journal of Canadian Studies 37, no. 4 (2002): 132.

10. Paul Axelrod, Scholars and Dollars (Toronto: UTP, 1982), 22-24; Jasen, 247-248.

11. Ryan Edwardson, Canadian Content (Toronto: UTP, 2008), a.151; b.152; c.172; d.150; e.168; f.152, 142; g.150; h.169-170; i.216$217 ;$ j. 171

12. Robert Rae, "In Defence of Student Activism: a Reply," in Student Power and the Canadian Campus, eds. Tim and Julyan Reid (Toronto: Peter Martin, 1969), 67.

13. "Request for a special meeting of C.U.A.S.A., November 25, 1968," in The Struggle for Canadian Universities, 14.

14. "Memorandum to C.U.A.S.A on de-Canadianization, and five motions, from Mathews and Steele," in The Struggle for Canadian Universities, a.19-20; b.18.

15. "Letter to Steele from C.U.A.S.A. Secretary, November 26, 1968," in The Struggle for Canadian Universities, 22.

16. "Announcement of special meeting of C.U.A.S.A., by Professor O'Neil (Secretary), December 5, 1968," in The Struggle for Canadian Universities, 26.

17. "Petition circulated by Professors McFarlane and Forcese," in The Struggle for Canadian Universities, 23.

18. "Memorandum on the McFarlane-Forcese petition by Mathews and Steele," in The Struggle for Canadian Universities, 24.

19. "Letter to Professor McFarlane from Mathews, December 18, 1968," in The Struggle for Canadian Universities, 38

20. "Extract from the minutes of the C.U.A.S.A. general meeting, December 11, 1968," in The Struggle for Canadian Universities, 35.

21. Robin Mathews and James Steele, "Canadianization Revisited," Canadian Journal of Sociology 31, no. 4 (2006): a.505; b.505; c. $492 ;$ d. 505 .

22. James Laxer, "The Student Movement and Canadian Independence," Canadian Dimension 6, no. 3 \& 4 (1969): 2. 
23. Cyril Levitt, Children of Privilege (Toronto: UTP, 1984), a.84; b.82.

24. Roberta Lexier, "The Backdrop Against Which Everything Happened," History of Intellectual Culture 7, no. 1 (2007): a.17; b.17.

25. Pete Warrian, "Education: Democratization and Decolonization," in Student Power and the Canadian Campus, 24.

26. Michael Walzer, "The New Left," in Student Power and the Canadian Campus, 19.

27. Ronald Weihs, "The Left and Centre of Campus Politics," University of Toronto Graduate 3, no. 1 (1969): a.39; b.34.

28. Claude Bissell, "How Democracy Works in a University Community," University of Toronto Graduate 2, no. 1 (1968): a.35; b.32.

29. Julyan Reid, "Some Canadian Issues," in Student Power and the Canadian Campus, 5.

30. Michael Butler and David Shugarman, "Canadian Nationalism, Americanization and Scholarly Values," Journal of Canadian Studies 5, no. 3 (1970): a.22; b.22; c.13-14, 25.

31. Melville H. Watkins, "Education in the Branch Plant Economy," in Canadian Dimension, Kit No. 3: Canadian Nationalism (Winnipeg: Canadian Dimension, 1970), 40.

32. Robin Mathews, "The Americanization of Canadian Universities," in Canadian Dimension, Kit No. 3, 37-39.

33. "Excerpt from a letter to the Canadian Forum by Professor Cook, published September, 1969," in The Struggle for Canadian Universities, a.139; b.139.

34. "Letter to The Globe and Mail from Professor Doyle, published June 28, 1969," in The Struggle for Canadian Universities, 136.
35. "Memorandum to C.U.A.S.A from Professor Gripton, December 10, 1968," in The Struggle for Canadian Universities, 29-31.

36. "Letter in The Globe and Mail from Professor Gustin, published May 30, 1969," in The Struggle for Canadian Universities, 125.

37. "Letter to Professor McFarlane from Mathews, January 12, 1969," in The Struggle for Canadian Universities, 54.

38. "Letter in The Globe and Mail from Professor Conway, published May 30, 1969," in The Struggle for Canadian Universities, a.126; b.126.

39. "Music: a letter from composer Barbara Pentland in Vancouver, May 25, 1969," in The Struggle for Canadian Universities, a.170; b.172.

40. Canada U.S. Relations: A Socialist Viewpoint (Toronto: Vanguard Publications, October 1969), 5.

41. Terence A. Crowley, "Anti-Americanism and the Degeneration of Canadian Scholarship: A Rejoinder," Journal of Canadian Studies 6, no. 2 (1971): a.52-54; b.54-57..

42. "Letter to Professor Frumhartz from Mathews, January 4, 1969," in The Struggle for Canadian Universities, 48.

43. Gad Horowitz, "On the Fear of Nationalism," in Canadian Dimension, Kit No. 3, 1.

44. Claude Bissell, "A Harvard Sabbatical," University of Toronto Graduate 1, no. 4 (1968): 18; 12.

45. Janet Scarfe and Edward Sheffield, "Notes on the Canadian Professoriate," Higher Education 6 (1977): 339.

46. Jeffrey J. Cormier, "The Impact of Movements: Bureaucratic Insurgency, Canadianization and the CSAA," Canadian Review of Sociology 41, no. 2 (2004): 212. 